\title{
CONSERVATION METHODS FOR NATIVE FRUIT SEEDS
}

\author{
Kelli Pirola ${ }^{1}$, Marcelo Dotto ${ }^{1}$, Darcieli Aparecida Cassol $^{1}$, Américo Wagner Júnior ${ }^{1}$, Jean Carlo \\ Possenti $^{1} \&$ Idemir Citadin ${ }^{1}$
}

\begin{abstract}
${ }^{1}$ Universidade Tecnológica Federal do Paraná. E-mail: kelli_pirola1@ @otmail.com, marcelodotto@ hotmail.com, so_darci@hotmail.com, americowagner@utfpr.edu.br,jpossenti@utfpr.edu.br, idemir@utfpr.edu.br
\end{abstract}

\begin{abstract}
The objective of this study was to establish conservation techniques for native fruit seeds. It was used guabijuzeiro, Surinan cherry tree, jabuticabeira de cabinho and cerejeira-do-mato seeds, divided into two lots, being applied cassava starch biofilms (6\%) and without the use of it. After, the seeds were divided into two groups, one for conservation in bottles of polyethylene terephthalate (PET) and other in waxed paper bag and stored for 18 periods up to 360 days until sowing. The experimental design was completely randomized blocks, in factorial 2 x 2 x 18 (storage packaging x biofilm x storage time), with 4 replications of one hundred seeds by plot. After 60 days of the beginning of experiment, the germination (\%) and emergence speed index (ESI) were evaluated. The PET bottle permitted greater conservation as increased the seed germination. The biofilm can be considered a promising technique to increase germination efficiency of cerejeira-da-mata.
\end{abstract}

Keywords: Storage, viability, Myrtaceae

\section{MÉTODOS DE CONSERVAÇÃO PARA SEMENTES DE FRUTEIRAS NATIVAS}

\section{RESUMO}

O objetivo deste trabalho foi estabelecer técnicas de conservação em sementes de fruteiras nativas. Foram utilizadas sementes de guabijú, pitangueira, jabuticabeira de cabinho e cerejeira-do-mato, separadas em dois lotes, sendo aplicado biofilme de fécula de mandioca (6\%) e sem a utilização deste. Após as sementes foram divididas em dois sub-lotes, um para conservação em garrafas de Polietileno Tereftalato (PET) e outro em saco de papel encerado, e armazenado por 18 períodos até 360 dias até semeadura. Foi utilizado delineamento inteiramente casualizado, em trifatorial 2 × 2 x 18 (embalagem de armazenamento x biofilme x período de armazenamento), com quatro repetições de 100 sementes. Após 60 dias, foram analisados a emergência (\%) e o índice de velocidade de emergência (IVE). A 
garrafa PET permitiu maior conservação aumentando o número de sementes germinadas das quatro fruteiras. O biofilme pode ser considerado técnica promissora para aumentar eficiência no processo germinativo de cerejeira-da-mata.

Palavras-chave: Armazenamento, viabilidade, Myrtaceae

\section{INTRODUCTION}

Brazil has a considerable area of native forest, with a great variety of fruit trees still little studied, same with a great potential of use. Thus, the lack of technical information makes it difficult to establish commercial orchards. This occurs with fruit trees of the Myrtaceae family (BÜLOW et al., 1994), especially within the genus Eugenia, Plinia, Campomanesia, and Myrcianthes.

As most of the species that make up this genus are not commercialized extensively. Thebasic information about the propagation, cultive and potentiality of its fruits forfood industry, cosmetics and pharmaceutics, being in the latter case as a functional food, besides the use of urban afforestation projects and the recovery of degraded areas, agroforestry and breeding programs within germplasm banks and even for their perpetuation, become necessary (SCALON et al., 2004).

In the case of propagation, the use of seed also prevails in order to obtain seedlings, which, although more used, has limitations in some aspects, such as the possible loss of viability with storage. This can occur rapidly, as observed by Pirola et al. (2009) and Danner et al. (2011) with jabuticabeira ("Acú" and "de Cabinho", respectively) occurring at ten and five days of storage.

This loss of viability in seeds of native fruit trees is related to their intolerance to desiccation, called as recalcitrance. Normally, it is necessary to use storage techniques with low temperature and humidity to preserve the viability of the seeds and this latter factor cannot be adopted in fruit trees that have recalcitrance. On the other hand, if the conservation environment has high humidity, germination can still occur in storage and/or fungi attack that could also prevent the seed to germinate.

Studies have already been carried out aiming at the conservation of the viability of Myrtaceae fruit seeds (RIZZINI, 1970; BÜLOW et al., 1994; BARBEDO et al., 1998; ANJOS \& FERRAZ 1999; MALUF et al., 2003), but have not yet presented an ideal technique to store them for prolonged periods (LORENZI, 1992, 2002).

In order to maintain seed viability during storage, it is necessary to start from a few assumptions (CARVALHO \& NAKAGAWA, 2000), among which the seed respiration is first mentioned, which 
must be kept to a minimum level in order to delay senescence, avoiding the excessive consumption of reserves and the degenerative oxidation (FOWLER, 2000). A factor that contributes to this is the reduction of the temperature that decreases the metabolic activities of the seed, which favours the viability of the seeds (BARBEDO et al., 2002).

Another factor to consider is the type of packaging, which must be defined by the permeability to water, according to the ease of water vapour exchanges between the seeds and the atmosphere of the environment where they are stored (MARCOS FILHO, 2005).

For recalcitrant seeds, the packaging that may contribute to its longevity concerns those that allow minimal exchange of gases. Thus, one could test those that modify the atmosphere reducing the concentration of oxygen and increase of carbon dioxide as applying biofilms as seed coating material.

Biofilms, when applied to seeds, consist of the deposition of a thin and uniform layer on the surface (DUAN \& BURRIS, 1997), providing protection against mechanical damages in the handling and penetration of microorganisms and insects, as well as regulating the entry of water and oxygen necessary for seed germination (MENEZES, 2003).

Biofilms are prepared from natural polymers such as polysaccharides (starch, carrageenan, alginates, etc.) and proteins (gelatine, casein, wheat gluten, etc.) (DAVANÇO et al., 2007). The application in the seeds, contribute to increase the viability, since they reduce their metabolic activity by limiting the gas exchanges with the external environment, making it impossible to germinate and at the same time keeping them conserved (ALEGRETTI et al., 2015).

Another way that can modify the atmosphere of conservation of the seed, much used by the farmer, is by the use of polyethylene terephthalate bottles with a screw cap, little tested in the scientific environment.

The impermeable packaging, such as polyethylene terephthalate bottles, presents as main advantages, in addition to avoiding the exchange of moisture of the seeds with the environment, the reduction of the loss of dry matter mass, besides the reduction of oxygen availability due to respiration of stored seeds in which carbon dioxide increases in the environment thereby maintaining the physiological quality of the seeds for longer periods of storage (BAUDET, 2003; SAUER, 1992).

As the objective of preserving recalcitrant seeds is to avoid during storage the loss of moisture, keeping it in a way that does not generate the beginning of the germination process one could test the use of pre-hydrocondicionament followed by its storage in packages that modify the atmosphere, increasing 
the moisture content of the seeds and thus reducing their metabolic activity, preventing the onset of the germination process related to catabolism.

Thus, the objective of this work was to verify and establish techniques of conservation by modified atmosphere in seeds of four native fruit trees.

\section{MATERIAL AND METHODS}

The work was carried out at the Laboratory of Plant Physiology, at the Universidade Tecnológica Federal do Paraná - Campus Dois Vizinhos, in the state of Paraná, Brazil. Seeds of mature fruits were used at the point of consumption of four native fruit trees, guabijú (Myrcianthes pungens), Surinan Cherry tree (Eugenia uniflora), jabuticabeira de cabinho (Plinia trunciflora) and cerejeira-da-mata (Eugenia involucrata). The extraction of the seeds of guabijú, cerejeira-da-mata and Surinan cherry tree was carried out by pulp removal manually. For jabuticabeira de cabinho, the pulp was also removed manually, however, by means of friction in a fine mesh sieve, adding lime virgin.

After 24 hours of the seeds extraction, the seeds were separated into two lots, the first one being biofilm based on cassava starch (6\%) and the second one without the use of the film, being only immersed in distilled water by one minute.

The biofilm was applied by means of the immersion of the seeds in the solution of the macromolecules during one minute, and the preparation of this one, based on cassava starch (6\%) was obtained by its solubilisation in water, with gentle and constant agitation, by heating it to the temperature of $80^{\circ} \mathrm{C}$ for approximately 15 minutes, thus obtaining the jellification of the macromolecules. Thereafter, the solution allowed to stand for one hour to achieve thermal equilibrium with the environment, and such application was then carried out on the seeds. After the application of the biofilm, the seeds were kept for 24 hours in shade, in plastic trays $(10.0 \times 16.0 \mathrm{~cm})$, for total drying of the macromolecule.

The biofilm-coated and water-immersed seeds were divided into two groups, one for storage in polyethylene terephthalate (PET) bottles of blue colour $(300 \mathrm{~mL})$, closed with their respective plastic

screw cap and another in a waxed white paper bag $(16.0 \times 9.0 \mathrm{~cm})$ closed at the end with one fold and then stapled.

The seeds in their respective packages were stored for periods of $0,5,10,15,20,25,30,60,90$, $120,150,180,210,240,270,300,330,360$ days. Both packages were kept at room temperature for the entire storage period. 
After each period, the seeds were removed from their containers and seeded in plastic trays (10.0 x $16.0 \mathrm{~cm}$ ) containing washed sand and autoclaved as substrate and kept on a shading screen (50\%).

The maximum and minimum temperatures during the execution of the experiment were described in Figure 1, followed by harvest period according to the production season of each fruit tree.

After 60 days, from each sowing in sand, the percentage of emergence (\%) and the emergence speed index (ESI) were evaluated. However, it was verified that in the bottles there were some germinated seeds, mainly after larger periods of storage, as occurred for cerejeira-da-mata, surinan cherry tree and jabuticabeira de cabinho, these data were accounted for only after the emergence of the seedlings in the substrate.

The experimental design was in a completely randomized block design, constituting a factorial $2 \mathrm{x}$ $2 \times 18$ (storage packaging $\mathrm{x}$ biofilm use $\mathrm{x}$ storage period), with 4 replicates of 100 seeds.

The data from emergence and ESI where submitted previously to Lilliefors' normality test and when needed, the same were transformed by sine arc $\sqrt{x / 100}$ and $\sqrt{x+1}$, respectively. Data were transformed for all variables, both for emergence and ESI, except for the emergence of cerejeira-da-mata. Subsequently, the means were submitted to analysis of variance and means comparison by the Duncan's test $(p=0.05)$ and regression analysis for the time factor. All analyses were performed by the computational application SANEST ${ }^{\circledR}$ (ZONTA \& MACHADO, 1984).

\section{RESULTS AND DISCUSSION}

According to the results, there was no triple interaction between the factors (packaging, storage time $\mathrm{x}$ biofilm use) within the analysed variables. However, there was a significant interaction between packing and storage time for emergence and ESI of all species (Tables 1, 3, 5, 6, and 7), except for ESI in guabijú. However, the interaction between biofilm and storage time was only significant for emergence and ESI of cerejeira-da-mata seeds (Table 2) and for guabijú trees only for ESI (Table 4), while for the other species there was no interaction.

By analysing the germination processes of the seeds of all species, it was verified that the emergence and ESI, for the time factor of storage, presented decreasing quadratic behaviour (Figures 1 and 2, respectively), decreasing drastically with the passage of their storage time. This demonstrates the rapid loss of viability of these seeds considered recalcitrant, an important fact as information for the management of these seeds when searching for seedlings. 
The seeds of cerejeira-da-mata were losing their germination capacity during the days of storage, already apparent within five days when kept in paper bag, having an emergence of $7 \%$. On the other hand, it was observed that these seeds when kept in PET bottles, remained viable longer, presenting about $60 \%$ emergence at 10 days (Table 1). The same was also observed with the ESI of these seeds (Table 1). However, from the $15^{\text {th }}$ day there was a drastic loss of viability.
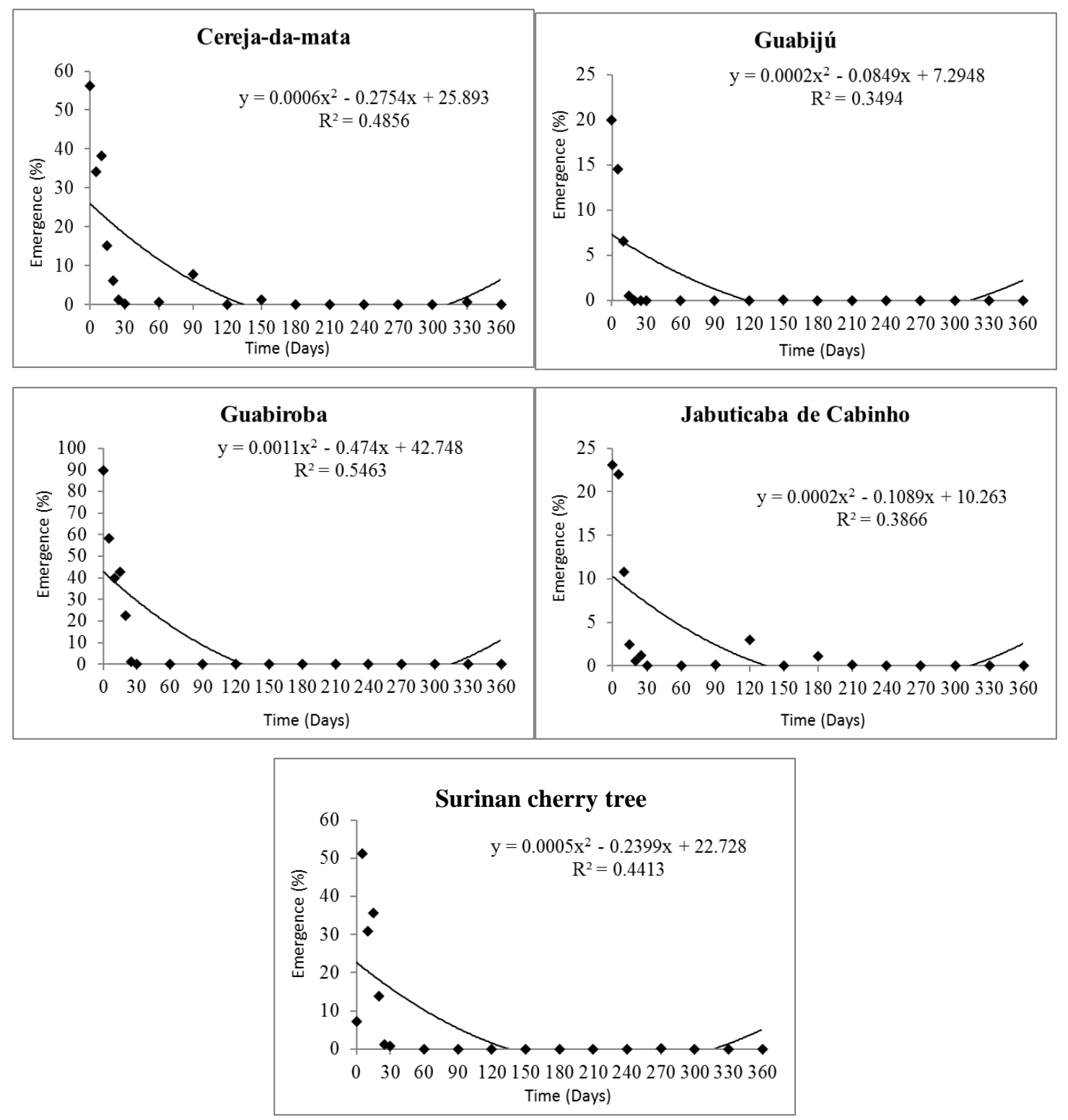

Figure 1. Emergence $(\%)$ of seeds from native fruit trees according to storage time. UTFPR, Dois Vizinhos - PR, 2013. 


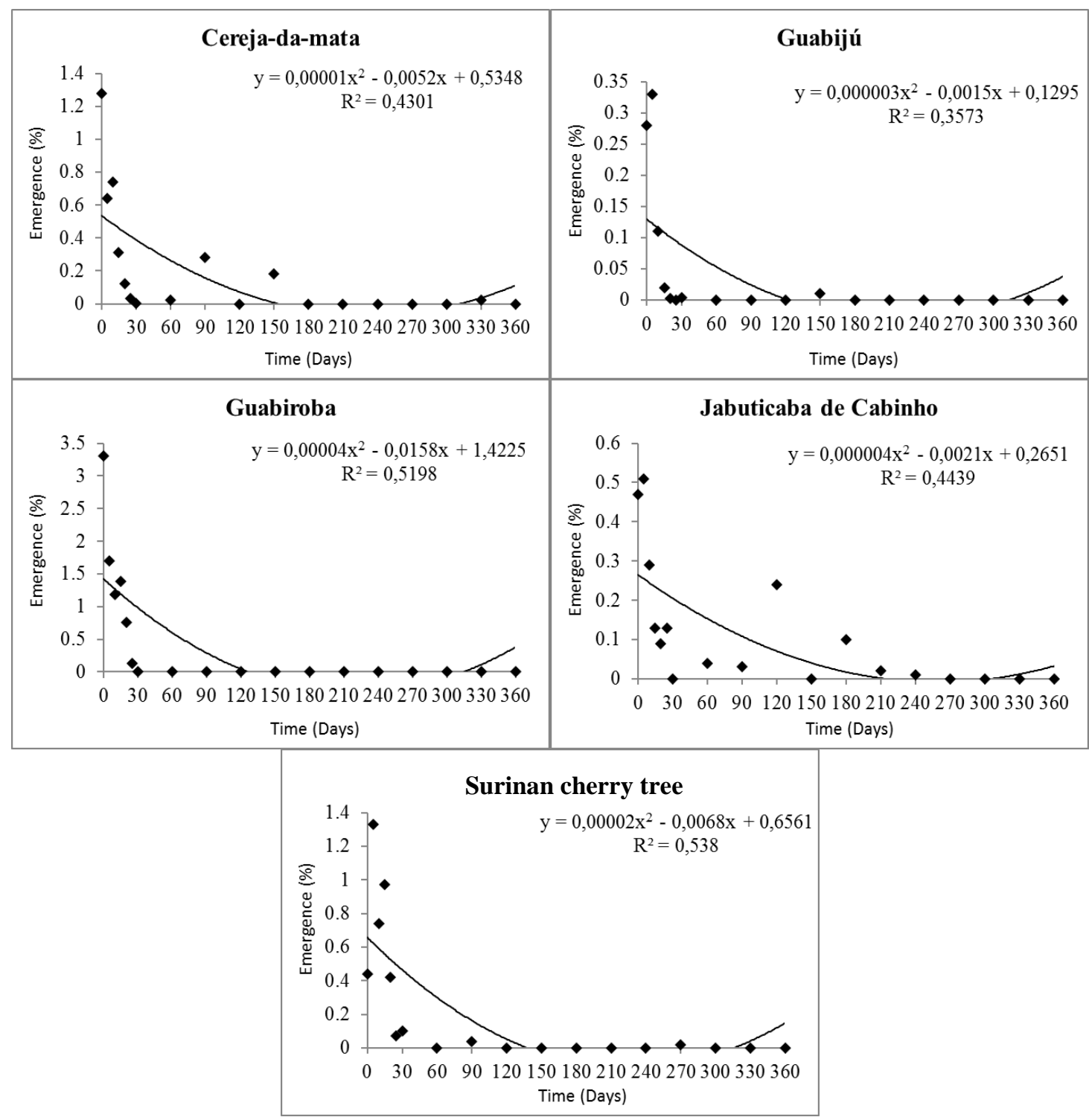

Figure 2. Emergence Speed Index (ESI) of seeds from native fruit trees according to storage time. UTFPR, Dois Vizinhos - PR, 2013.

The greatest maintenance of the viability of cerejeira-da-mata seeds was with the use of the PET bottles in comparison to the paper bag, that may have been due to this packaging allows less exchange of moisture and gases with the environment, conserving for a longer time the viability of germination, especially those that do not tolerate desiccation, as is the case of this species, as described by Wielwicki et al. (2006). Loss of water during storage may result in structural mechanical damage that is not corrected even during rehydration (CASTRO et al., 2004), which may have affected the germination process, which may have occurred in seeds kept in paper bags (Table 1). 
Table 1. Emergence (\%) and emergence speed index (ESI) of cerejeira-da-mata (E. involucrata) seeds according to the packing type and storage time. UTFPR, Dois Vizinhos - PR, 2013.

\begin{tabular}{|c|c|c|c|c|}
\hline \multirow{2}{*}{ Time (dias) } & \multicolumn{2}{|c|}{ Emergence (\%) } & \multicolumn{2}{|c|}{ ESI } \\
\hline & Paper bag & PET bottle & Paper bag & PET bottle \\
\hline 0 & 56,25 a $A^{*}$ & 56,25 a $A$ & $1,28 \mathrm{a} \mathrm{A}^{*}$ & 1,28 a $\mathrm{A}$ \\
\hline 5 & $6,75 \mathrm{bc} \mathrm{B}$ & 61,50 a $\mathrm{A}$ & 0,12 bc B & 1,26 a $\mathrm{A}$ \\
\hline 10 & 13,12 b B & 63,37 a $A$ & $0,20 \mathrm{bc} \mathrm{B}$ & 1,38 a $\mathrm{A}$ \\
\hline 15 & $1,50 \mathrm{c} \mathrm{B}$ & $28,75 \mathrm{~b} \mathrm{~A}$ & 0,03 с B & $0,63 \mathrm{~b} \mathrm{~A}$ \\
\hline 20 & 3,12 c A & $9,25 \mathrm{~cd} \mathrm{~A}$ & $0,06 \mathrm{bc} \mathrm{A}$ & 0,19 с A \\
\hline 25 & 0,50 c $A$ & $2,00 \mathrm{dA}$ & $0,01 \mathrm{c} \mathrm{A}$ & 0,04 c A \\
\hline 30 & $0,25 \mathrm{cA}$ & $0,00 \mathrm{~d} A$ & $0,005 \mathrm{c} \mathrm{A}$ & 0,00 с A \\
\hline 60 & $0,00 \subset \mathrm{A}$ & $1,12 \mathrm{~d} A$ & 0,00 c A & 0,03 с A \\
\hline 90 & 0,00 c B & $15,75 \mathrm{c} \mathrm{A}$ & 0,00 c B & $0,60 \mathrm{~b} \mathrm{~A}$ \\
\hline 120 & 0,00 c A & $0,00 \mathrm{~d} A$ & 0,00 c A & 0,00 c A \\
\hline 150 & $0,25 \mathrm{cA}$ & $2,12 \mathrm{dA}$ & $0,33 \mathrm{~b} \mathrm{~A}$ & 0,00 с B \\
\hline 180 & 0,00 c A & $0,00 \mathrm{~d} A$ & 0,00 c A & $0,00 \subset A$ \\
\hline 210 & 0,00 c A & $0,00 \mathrm{~d} A$ & 0,00 с A & 0,00 c A \\
\hline 240 & 0,00 c A & $0,00 \mathrm{~d} A$ & 0,00 с A & 0,00 с A \\
\hline 270 & 0,00 с A & $0,00 \mathrm{~d} A$ & $0,00 \mathrm{cA}$ & 0,00 с A \\
\hline 300 & $0,00 \subset \mathrm{A}$ & $0,00 \mathrm{~d} A$ & 0,00 c A & 0,00 c A \\
\hline 330 & 0,00 c A & $1,37 \mathrm{~d} A$ & 0,00 c A & 0,05 c A \\
\hline 360 & 0,00 c A & $0,00 \mathrm{~d} A$ & 0,00 c A & $0,00 \mathrm{c} \mathrm{A}$ \\
\hline $\mathrm{CV}(\%)$ & \multicolumn{2}{|c|}{99,96} & \multicolumn{2}{|c|}{11,60} \\
\hline
\end{tabular}

"Means with different letters, lowercase in columns and highercase in rows, differ by Duncan's test $(p=0,05)$.

Regarding the biofilm-based application of cassava starch to preserve cerejeira-da-mata seeds (Table 2), it was found that it appeared to be effective for greater seed emergence in the 0-day storage period, presenting $69 \%$, whereas, without the use of it at the same time was $43 \%$. For ESI, at the same time, there was also a higher mean with biofilm use (Table 2). However, the seeds with the biofilm resembled those that did not adopt this macromolecule at 5, 10, 15, 20, 25, 30, 60, 120, 180, 210, 240, 270, 300, 330, and 360 days of storage for emergence and ESI (Table 2).

It was observed that at 90, 150 and 330 days, when no seed coating was used, there was seed emergence, a fact not obtained with the biofilm (Table 2). This emergence in these periods may be related to the temperature of the environment, since the experiment started in October 2011, and coincided with the months of highest temperature (December 2011, February 2012 and August 2012, respectively) (Figure 3).

The temperature changes the rate of water absorption and the biochemical reactions that trigger the metabolism, transport and re-synthesis (CARVALHO \& NAKAGAWA, 1988; BEWLEY \& BLACK, 1994), necessary for germination. The seeds have a very variable behaviour in relation to the 
temperature factor, not one considered optimal for all species (BORGES \& RENA, 1993). However, Piña-Rodrigues et al. (2004) indicated the range between $15^{\circ} \mathrm{C}$ and $30^{\circ} \mathrm{C}$ for most species. In the case of native species, seeds of the genus Eugenia germinate and develop normal seedlings adequately in the temperature range of $20^{\circ} \mathrm{C}$ to $30^{\circ} \mathrm{C}$ (LAMARCA et al., 2011).

Table 2. Emergence (\%) and emergence speed index (ESI) of cerejeira-da-mata (E. involucrata) seeds according to adoption or not of the biofilm and storage time. UTFPR, Dois Vizinhos - PR, 2013.

\begin{tabular}{|c|c|c|c|c|}
\hline \multirow{2}{*}{ Time (days) } & \multicolumn{2}{|c|}{ Germination $(\%)$} & \multicolumn{2}{|c|}{ ESI } \\
\hline & Without biofilm & With biofilm & Without biofilm & With biofilm \\
\hline 0 & $43,50 \mathrm{a} \mathrm{B}^{*}$ & 69,00 a $\mathrm{A}$ & $0,91 \mathrm{a} \mathrm{B}^{*}$ & 1,68 a $\mathrm{A}$ \\
\hline 5 & $38,50 \mathrm{ab} \mathrm{A}$ & 29,75 c A & 0,72 a $A$ & $0,56 \mathrm{bc} \mathrm{A}$ \\
\hline 10 & $34,12 \mathrm{~b} \mathrm{~A}$ & $42,37 \mathrm{~b} \mathrm{~A}$ & $0,63 \mathrm{ab} A$ & $0,85 \mathrm{~b} \mathrm{~A}$ \\
\hline 15 & $13,37 \mathrm{~cd} \mathrm{~A}$ & $16,87 \mathrm{~d} \mathrm{~A}$ & $0,28 \mathrm{~cd} \mathrm{~A}$ & $0,34 \mathrm{~cd} \mathrm{~A}$ \\
\hline 20 & 4,75 de $\mathrm{A}$ & 7,62 e $A$ & $0,09 \operatorname{cd} A$ & 0,16 de $A$ \\
\hline 25 & 0,25 e $A$ & 2,25 e $A$ & $0,005 \mathrm{~d} \mathrm{~A}$ & 0,05 e $A$ \\
\hline 30 & 0,12 e $A$ & 0,12 e $A$ & $0,002 \mathrm{~d} \mathrm{~A}$ & 0,002 e $A$ \\
\hline 60 & 1,12 e $A$ & 0,00 e $A$ & $0,03 \mathrm{~d} A$ & 0,00 e $\mathrm{A}$ \\
\hline 90 & $15,75 \mathrm{c} \mathrm{A}$ & 0,00 e $B$ & $0,60 \mathrm{ab} A$ & 0,00 e $B$ \\
\hline 120 & 0,00 e $A$ & 0,00 e $A$ & $0,00 \mathrm{~d} A$ & 0,00 e $A$ \\
\hline 150 & 1,50 e $A$ & 0,87 e $A$ & $0,36 \mathrm{bc} \mathrm{A}$ & 0,02 e $B$ \\
\hline 180 & 0,00 e $A$ & 0,00 e $A$ & $0,00 \mathrm{~d} A$ & 0,00 e $A$ \\
\hline 210 & 0,00 e $A$ & 0,00 e $A$ & $0,00 \mathrm{~d} A$ & 0,00 e $A$ \\
\hline 240 & 0,00 e $A$ & 0,00 e $A$ & $0,00 \mathrm{~d} A$ & 0,00 e $A$ \\
\hline 270 & 0,00 e $A$ & 0,00 e $A$ & $0,00 \mathrm{~d} A$ & 0,00 e $A$ \\
\hline 300 & 0,00 e $A$ & 0,00 e $A$ & $0,00 \mathrm{~d} A$ & 0,00 e $A$ \\
\hline 330 & 1,37 e $A$ & 0,00 e $A$ & $0,05 \mathrm{~d} A$ & 0,00 e $A$ \\
\hline 360 & 0,00 e $A$ & 0,00 e $A$ & $0,00 \mathrm{~d} A$ & 0,00 e $A$ \\
\hline $\mathrm{CV}(\%)$ & \multicolumn{2}{|c|}{99,96} & \multicolumn{2}{|c|}{11,60} \\
\hline
\end{tabular}

"Means with different letters, lowercase in the column and highercase in the row, differ by Duncan's test $(p=0,05)$.

Analysing the type of packaging used to preserve the seeds of guabijú, it was verified that when they were kept in PET bottles, there was superiority at 10 and 15 days compared to those kept in waxed paper bags. However, on the other days of storage there was no statistical difference between the different packages (Table 3).

It was observed that seeds held in waxed paper bags became non-viable from the fifteenth day of storage and those held in PET bottles on the twentieth day. However, in general, the emergence of guabijú seeds was relatively low from the beginning, not higher than $20 \%$ at day 0 (Table 3 ), which may be related to the presence of some type of dormancy. 


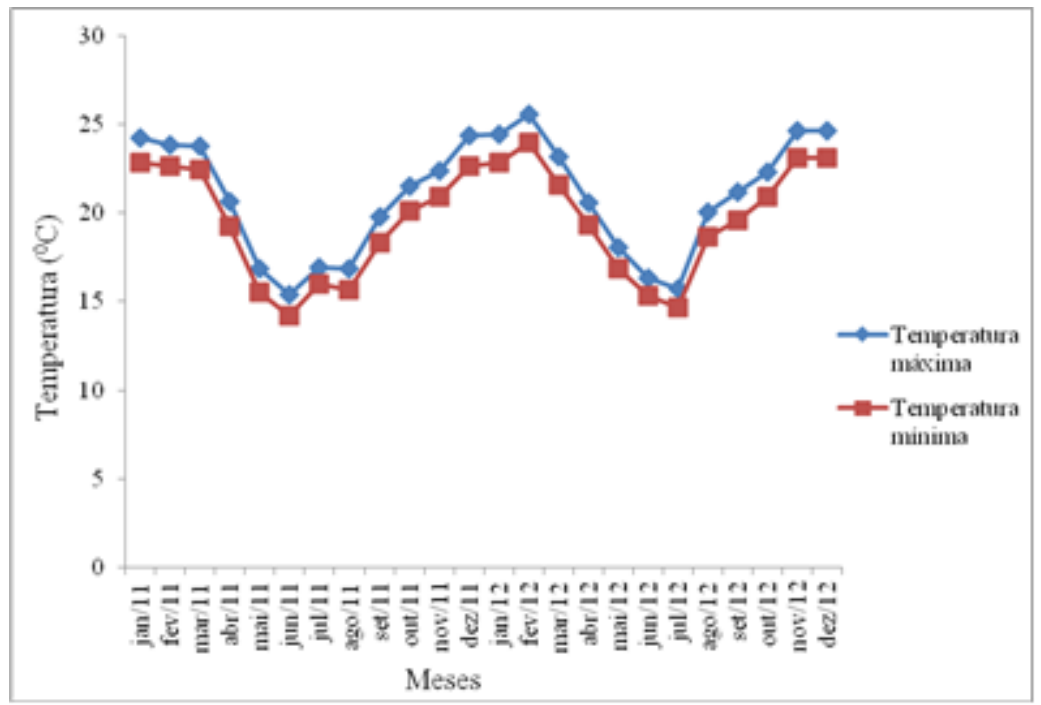

Figure 3: Maximum and minimum temperature according to the months during the execution of the experiment, for jabuticabeira de cabinho and cerejeira-da-mata, the beginning of the experiment was in October 2011; for Surinan cherry tree in November 2011; for guabijú in December 2011. UTFPR, Dois Vizinhos - PR, 2013.

Table 3. Emergence (\%) of guabijú (M. pungens) seeds according to packaging type and storage time. UTFPR, Dois Vizinhos - PR, 2013.

\begin{tabular}{ccc}
\hline \multirow{2}{*}{ Storage time (days) } & \multicolumn{2}{c}{ Packaging type } \\
\cline { 2 - 3 } & Paper bag & PET bottle \\
\hline 5 & $20,00 \mathrm{a} \mathrm{A}^{*}$ & $20,00 \mathrm{a} \mathrm{A}$ \\
10 & $11,73 \mathrm{~b} \mathrm{~A}$ & $17,54 \mathrm{ab} \mathrm{A}$ \\
15 & $2,40 \mathrm{c} \mathrm{B}$ & $12,60 \mathrm{~b} \mathrm{~A}$ \\
20 & $0,00 \mathrm{~d} \mathrm{~B}$ & $2,00 \mathrm{c} \mathrm{A}$ \\
25 & $0,05 \mathrm{~d} \mathrm{~A}$ & $0,00 \mathrm{~d} \mathrm{~A}$ \\
30 & $0,00 \mathrm{~d} \mathrm{~A}$ & $0,00 \mathrm{~d} \mathrm{~A}$ \\
60 & $0,00 \mathrm{~d} \mathrm{~A}$ & $0,05 \mathrm{~d} \mathrm{~A}$ \\
90 & $0,00 \mathrm{~d} \mathrm{~A}$ & $0,00 \mathrm{~d} \mathrm{~A}$ \\
120 & $0,00 \mathrm{~d} \mathrm{~A}$ & $0,00 \mathrm{~d} \mathrm{~A}$ \\
150 & $0,00 \mathrm{~d} \mathrm{~A}$ & $0,00 \mathrm{~d} \mathrm{~A}$ \\
180 & $0,00 \mathrm{~d} \mathrm{~A}$ & $0,22 \mathrm{~d} \mathrm{~A}$ \\
210 & $0,00 \mathrm{~d} \mathrm{~A}$ & $0,00 \mathrm{~d} \mathrm{~A}$ \\
240 & $0,00 \mathrm{~d} \mathrm{~A}$ & $0,00 \mathrm{~d} \mathrm{~A}$ \\
270 & $0,00 \mathrm{~d} \mathrm{~A}$ & $0,00 \mathrm{~d} \mathrm{~A}$ \\
300 & $0,00 \mathrm{~d} \mathrm{~A}$ & $0,00 \mathrm{~d} \mathrm{~A}$ \\
330 & $0,00 \mathrm{~d} \mathrm{~A}$ & $0,00 \mathrm{~d} \mathrm{~A}$ \\
360 & $0,00 \mathrm{~d} \mathrm{~A}$ & $0,00 \mathrm{~d} \mathrm{~A}$ \\
CV $(\%)$ & $0,00 \mathrm{~d} \mathrm{~A}$ & $0,00 \mathrm{~d} \mathrm{~A}$ \\
\hline
\end{tabular}

*Means with different letters, lowercase in the column and highercase in the row, differ by Duncan's test $(\mathrm{p}=0,05)$. 
Regarding the use of biofilm as a coat, for the variable ESI (Table 4), guabijú seeds with the biofilm did not show superior results over uncoated ones, resembling statistically in almost every day of storage, except for 5 days, in which presented inferiority. This demonstrates that the use of biofilm for storage of guabijú seeds was not advantageous, and other techniques were necessary to preserve them.

Table 4. Emergence Speed Index (ESI) of guabijú (M. pungens) seeds according to the adoption of not of the biofilm and storage time. UTFPR, Dois Vizinhos - PR, 2013.

\begin{tabular}{ccc}
\hline \multirow{2}{*}{ Storage time (days) } & \multicolumn{2}{c}{ Biofilm } \\
\cline { 2 - 3 } & Without biofilm & With biofilm \\
\hline 0 & $0,33 \mathrm{~b} \mathrm{~A}$ & $0,22 \mathrm{a} \mathrm{A}$ \\
5 & $0,52 \mathrm{a} \mathrm{A}$ & $0,16 \mathrm{ab} \mathrm{B}$ \\
15 & $0,15 \mathrm{c} \mathrm{A}$ & $0,07 \mathrm{bc} \mathrm{A}$ \\
20 & $0,02 \mathrm{~d} \mathrm{~A}$ & $0,02 \mathrm{c} \mathrm{A}$ \\
25 & $0,006 \mathrm{~d} \mathrm{~A}$ & $0,00 \mathrm{c} \mathrm{A}$ \\
30 & $0,00 \mathrm{~d} \mathrm{~A}$ & $0,00 \mathrm{c} \mathrm{A}$ \\
60 & $0,00 \mathrm{~d} \mathrm{~A}$ & $0,01 \mathrm{c} \mathrm{A}$ \\
90 & $0,00 \mathrm{~d} \mathrm{~A}$ & $0,00 \mathrm{c} \mathrm{A}$ \\
120 & $0,00 \mathrm{~d} \mathrm{~A}$ & $0,00 \mathrm{c} \mathrm{A}$ \\
150 & $0,00 \mathrm{~d} \mathrm{~A}$ & $0,00 \mathrm{c} \mathrm{A}$ \\
180 & $0,03 \mathrm{~d} \mathrm{~A}$ & $0,00 \mathrm{c} \mathrm{A}$ \\
210 & $0,00 \mathrm{~d} \mathrm{~A}$ & $0,00 \mathrm{c} \mathrm{A}$ \\
240 & $0,00 \mathrm{~d} \mathrm{~A}$ & $0,00 \mathrm{c} \mathrm{A}$ \\
270 & $0,00 \mathrm{~d} \mathrm{~A}$ & $0,00 \mathrm{c} \mathrm{A}$ \\
300 & $0,00 \mathrm{~d} \mathrm{~A}$ & $0,00 \mathrm{c} \mathrm{A}$ \\
330 & $0,00 \mathrm{~d} \mathrm{~A}$ & $0,00 \mathrm{c} \mathrm{A}$ \\
360 & $0,00 \mathrm{~d} \mathrm{~A}$ & $0,00 \mathrm{c} \mathrm{A}$ \\
CV & $0,00 \mathrm{~d} \mathrm{~A}$ & $0,00 \mathrm{c} \mathrm{A}$ \\
\hline
\end{tabular}

"Means with different letters, lowercase in the column and highercase in the row, differ by Duncan's test $(\mathrm{p}=0,05)$.

The emergence and ESI of jabuticaba de cabinho seeds kept in PET bottles were higher than those stored in paper bags during the 5, 10, 15, 25, and 120 days, and in the 180 days of the first variable described. Within the PET bottles, the emergence and ESI were higher in the 5 and 10 days compared to the other periods (Table 5). On the other hand, in the paper bags the superiority of these variables occurred only on day 0. In a study by Danner et al. (2011), under normal atmosphere, the seeds of jabuticaba are conserved for only five days, maintaining greater viability under ambient temperature.

For ESI, the seeds kept in PET bottles were higher than those stored in paper bags during the 5, 10, 15, 25, and 120 days. Within the PET bottles, ESI was higher in the 5 and 10 days compared to the other periods, and within the paper bags the superiority of this variable only occurred on day 0 (Table 5).

With this, it was noticed that the use of the PET bottles can also be recommended for this species, since it has proven to be advantageous for its conservation, even in a short period of time. 
It was observed that for seeds of jabuticabeira de cabinho stored in PET bottles, there was an emergence up to 180 days (Table 5). It was also observed advantages of the use of these packages by Souza Júnior et al. (2011), where they verified that the PET bottles provide favourable conditions of conservation to the seeds, guaranteeing better quality and for a longer period of storage.

According to Baudet (2003) and Sauer (1992), impermeable packaging, such as PET bottles, presents as main advantages, in addition to avoiding the exchange of seed moisture with the environment, reducing the availability of oxygen due to seed respiration when stored, which reduces the loss of dry matter, the proliferation of insects and maintains the physiological quality of the seeds for longer periods of storage. Improvements with the use of PET bottles were also observed for ESI (Table 5).

As for the Surinan cherry tree, it was observed that the emergence of the seeds when stored in PET bottles for 5, 15 and 20 days was superior to those kept in paper bags. The same occurred with ESI, including in this variable the same superiority of the PET bottle at 10 days.

However, in the paper bag it was possible to obtain emergence until the period of 30 days although very low, fact that did not occur with the PET bottle that conserved the seeds until the 25 days. When the emergence of the seeds inside each package was compared, in the different periods, the PET bottle was superior at 5 and 15 days and in the paper bag when 5, 10 and 15 days were maintained (Table 6).

Table 5. Emergence (\%) and emergence speed index (ESI) of jabuticabeira de cabinho (P. trunciflora) seeds according to packaging type and storage time. UTFPR, Dois Vizinhos - PR, 2013.

\begin{tabular}{c|cc|cc}
\hline \multirow{2}{*}{ Time (days) } & \multicolumn{2}{c}{ Germination } & \multicolumn{2}{c}{ ESI } \\
\cline { 2 - 5 } & $23,02 \mathrm{a} \mathrm{A}^{*}$ & $23,02 \mathrm{bc} \mathrm{A}$ & $0,47 \mathrm{a} \mathrm{A}{ }^{*}$ & $0,47 \mathrm{bc} \mathrm{A}$ \\
\hline 0 & $7,19 \mathrm{~b} \mathrm{~B}$ & $41,93 \mathrm{a} \mathrm{A}$ & $0,18 \mathrm{~b} \mathrm{~B}$ & $0,87 \mathrm{a} \mathrm{A}$ \\
10 & $1,45 \mathrm{bc} \mathrm{B}$ & $27,14 \mathrm{ab} \mathrm{A}$ & $0,04 \mathrm{~b} \mathrm{~B}$ & $0,58 \mathrm{ab} \mathrm{A}$ \\
15 & $0,00 \mathrm{c} \mathrm{B}$ & $9,58 \mathrm{~cd} \mathrm{~A}$ & $0,00 \mathrm{~b} \mathrm{~B}$ & $0,26 \mathrm{~cd} \mathrm{~A}$ \\
20 & $0,03 \mathrm{c} \mathrm{A}$ & $1,80 \mathrm{de} \mathrm{A}$ & $0,003 \mathrm{~b} \mathrm{~A}$ & $0,18 \mathrm{~cd} \mathrm{~A}$ \\
25 & $0,00 \mathrm{c} \mathrm{B}$ & $4,66 \mathrm{de} \mathrm{A}$ & $0,00 \mathrm{~b} \mathrm{~B}$ & $0,27 \mathrm{~cd} \mathrm{~A}$ \\
30 & $0,00 \mathrm{c} \mathrm{A}$ & $0,00 \mathrm{e} \mathrm{A}$ & $0,00 \mathrm{~b} \mathrm{~A}$ & $0,00 \mathrm{~d} \mathrm{~A}$ \\
60 & $0,00 \mathrm{c} \mathrm{A}$ & $0,21 \mathrm{e} \mathrm{A}$ & $0,00 \mathrm{~b} \mathrm{~A}$ & $0,07 \mathrm{~d} \mathrm{~A}$ \\
90 & $0,00 \mathrm{c} \mathrm{A}$ & $0,50 \mathrm{e} \mathrm{A}$ & $0,00 \mathrm{~b} \mathrm{~A}$ & $0,06 \mathrm{~d} \mathrm{~A}$ \\
120 & $0,11 \mathrm{c} \mathrm{B}$ & $9,44 \mathrm{~cd} \mathrm{~A}$ & $0,01 \mathrm{~b} \mathrm{~B}$ & $0,00 \mathrm{~d} \mathrm{~A}$ \\
150 & $0,00 \mathrm{c} \mathrm{A}$ & $0,00 \mathrm{e} \mathrm{A}$ & $0,00 \mathrm{~b} \mathrm{~A}$ & $0,20 \mathrm{~cd} \mathrm{~A}$ \\
180 & $0,00 \mathrm{c} \mathrm{B}$ & $4,47 \mathrm{de} \mathrm{A}$ & $0,00 \mathrm{~b} \mathrm{~A}$ & $0,04 \mathrm{~d} \mathrm{~A}$ \\
210 & $0,00 \mathrm{c} \mathrm{A}$ & $0,47 \mathrm{e} \mathrm{A}$ & $0,00 \mathrm{~b} \mathrm{~A}$ & $0,01 \mathrm{~d} \mathrm{~A}$ \\
240 & $0,03 \mathrm{c} \mathrm{A}$ & $0,06 \mathrm{e} \mathrm{A}$ & $0,008 \mathrm{~b} \mathrm{~A}$ & $0,00 \mathrm{~d} \mathrm{~A}$ \\
270 & $0,00 \mathrm{c} \mathrm{A}$ & $0,00 \mathrm{e} \mathrm{A}$ & $0,00 \mathrm{~b} \mathrm{~A}$ & $0,00 \mathrm{~d} \mathrm{~A}$ \\
300 & $0,00 \mathrm{c} \mathrm{A}$ & $0,00 \mathrm{e} \mathrm{A}$ & $0,00 \mathrm{~b} \mathrm{~A}$ & $0,00 \mathrm{~d} \mathrm{~A}$ \\
330 & $0,00 \mathrm{c} \mathrm{A}$ & $0,00 \mathrm{e} \mathrm{A}$ & $0,00 \mathrm{~b} \mathrm{~A}$ & $0,00 \mathrm{~d} \mathrm{~A}$ \\
360 & $0,00 \mathrm{c} \mathrm{A}$ & $0,00 \mathrm{e} \mathrm{A}$ & $0,00 \mathrm{~b} \mathrm{~A}$ & \\
\hline CV & & & 9,66 \\
\hline
\end{tabular}

*Means with different letters, lowercase in the column and highercase in the row, differ by Duncan's test $(\mathrm{p}=0,05)$. 
Table 6. Germination (\%) and emergence speed index (ESI) of Surinan cherry tree (E. uniflora) seeds according to packaging type and storage time. UTFPR, Dois Vizinhos - PR, 2013.

\begin{tabular}{|c|c|c|c|c|}
\hline \multirow{2}{*}{ Time (days) } & \multicolumn{2}{|c|}{ Germination } & \multicolumn{2}{|c|}{ ESI } \\
\hline & Paper bag & PET bottle & Paper bag & PET bottle \\
\hline 0 & $7,15 \mathrm{~b} \mathrm{~A}^{*}$ & 7,15 c A & 0,44 abc $\mathrm{A}^{*}$ & $0,44 \mathrm{~d} \mathrm{~A}$ \\
\hline 5 & 31,64 a B & 70,65 a $\mathrm{A}$ & 0,75 a $\mathrm{B}$ & 1,98 a $\mathrm{A}$ \\
\hline 10 & 28,44 a $\mathrm{A}$ & $33,50 \mathrm{~b} \mathrm{~A}$ & 0,67 a B & 0,82 с A \\
\hline 15 & 19,17 a B & 54,27 a A & $0,52 \mathrm{ab} B$ & 1,49 b A \\
\hline 20 & $2,77 \mathrm{bc} \mathrm{B}$ & $31,38 \mathrm{~b} \mathrm{~A}$ & $0,10 \mathrm{~cd} \mathrm{~B}$ & $0,79 \mathrm{~cd} \mathrm{~A}$ \\
\hline 25 & 2,11 bc $\mathrm{A}$ & $0,58 \mathrm{~d} \mathrm{~A}$ & $0,12 \mathrm{~cd} \mathrm{~A}$ & 0,02 e $A$ \\
\hline 30 & 3,46 bc A & $0,00 \mathrm{~d} B$ & $0,20 \mathrm{bcd} A$ & 0,00 e $\mathrm{A}$ \\
\hline 60 & 0,00 c A & $0,00 \mathrm{~d} A$ & $0,00 \mathrm{~d} A$ & 0,00 e $\mathrm{A}$ \\
\hline 90 & $0,00 \mathrm{cA}$ & $0,26 \mathrm{~d} \mathrm{~A}$ & $0,00 \mathrm{~d} A$ & 0,09 e $\mathrm{A}$ \\
\hline 120 & 0,00 c A & $0,00 \mathrm{~d} \mathrm{~A}$ & $0,00 \mathrm{~d} \mathrm{~A}$ & 0,00 e $\mathrm{A}$ \\
\hline 150 & $0,00 \mathrm{cA}$ & $0,00 \mathrm{~d} A$ & $0,00 \mathrm{~d} A$ & 0,00 e $A$ \\
\hline 180 & $0,00 \mathrm{cA}$ & $0,00 \mathrm{~d} A$ & $0,00 \mathrm{~d} \mathrm{~A}$ & 0,00 e $A$ \\
\hline 210 & $0,00 \subset \mathrm{A}$ & $0,00 \mathrm{dA}$ & $0,00 \mathrm{dA}$ & 0,00 e $A$ \\
\hline 240 & $0,00 \mathrm{c} \mathrm{A}$ & $0,00 \mathrm{~d} A$ & $0,00 \mathrm{~d} A$ & 0,00 e $A$ \\
\hline 270 & $0,00 \mathrm{cA}$ & $0,32 \mathrm{dA}$ & $0,00 \mathrm{~d} A$ & 0,03 e $A$ \\
\hline 300 & $0,00 \subset \mathrm{A}$ & $0,00 \mathrm{dA}$ & $0,00 \mathrm{dA}$ & 0,00 e $A$ \\
\hline 330 & 0,00 c A & $0,00 \mathrm{~d} A$ & $0,00 \mathrm{~d} A$ & 0,00 e $\mathrm{A}$ \\
\hline 360 & $0,00 \subset \mathrm{A}$ & $0,00 \mathrm{~d} A$ & $0,00 \mathrm{dA}$ & 0,00 e $A$ \\
\hline $\mathrm{CV}(\%)$ & \multicolumn{2}{|c|}{96,18} & \multicolumn{2}{|c|}{11,38} \\
\hline
\end{tabular}

${ }^{*}$ Means with different letters, lowercase in the column and highercase in the row, differ by Duncan's test $(p=0,05)$.

In general, although the PET bottle presented higher values for emergence in the initial periods of storage, it was noticed that the paper packaging allowed the conservation of the seeds of the native fruit trees for a short period. According to Carneiro (1987), the packaging used in storage plays an important role in maintaining the initial vigour of the seeds.

However, attention should be paid to the fact that there were emergencies of cherry-wood seeds, as well as jabuticabeira de cabinho and Surinan cherry tree inside PET bottles when stored for 330, 300 and 270 days, respectively. These seeds, when removed from this package and sowed in sand, have remained viable, allowing their emergence and subsequent normal development, which may make it a new conservation technique, in which case it must first be tested.

The conservation of the recalcitrant seeds can be obtained with methods that aim at stopping or limiting the growth of the embryonic axis, keeping the seed in a medium sufficiently hydrated to avoid its dehydration below the critical water content (CHIN et al., 1989) thus making the use of the PET bottles promising to avoid the excessive water loss. 


\section{CONCLUSIONS}

The PET bottle allowed greater conservation by increasing the number of seeds germinated for the four native fruit trees. In the germinating process of cerejeira-da-mata, biofilm can be considered a promising technique to increase efficiency.

\section{REFERENCES}

ALEGRETTI, A. L.; WAGNER JÚNIOR, A.; BORTOLINI, A.; HOSSEL, C.; ZANELA, J.; CITADIN, I. 2015. Armazenamento de sementes de cerejas-do-mato (Eugenia involucrata) DC. submetidas ao recobrimento com biofilmes e embalagem a vácuo. Revista Ceres, Viçosa, v.62, n.1, p. 124-127.

ANJOS, A.M.G.; FERRAZ, I.D.K. 1999. Morfologia, germinação e teor de água das sementes de araçáboi (Eugenia stipitata ssp. sororia). Acta Amazonica, Manaus, v.29, p.337-348.

BARBEDO, C. J.; KOHAMA, S.; MALUF, A. M.; BILIA, D. A. C. 1998. Germinação e armazenamento de diásporos de cerejeira (Eugenia involucrata DC. - Myrtaceae) em função do teor de água. Revista Brasileira de Sementes, Londrina, v.20, p.184-188.

BARBEDO, C. J.; BILIA, D. A. C.; FIGUEIREDO-RIBEIRO, R. C. L. 2002. Tolerância à dessecação e armazenamento de sementes de Caesalpinia echinata Lam. (Pau-Brasil), espécie da Mata Atlântica. Revista Brasileira de Botânica, São Paulo, v.25, n.4, p.431-439.

BAUDET, L.M.L. 2003. Armazenamento de sementes. In: PESKE, S.T.; ROSENTAL, M.D.; ROTA, G.R. (ed.). Sementes: fundamentos científicos e tecnológicos, Pelotas: Ed. Universitária - UFPel, p.370-418.

BEWLEY, J. D.; BLACK, M. 1994. Seeds: physiology of development and germination. New York: Plenum Press.

BORGES, E.E. de L.e; RENA, A.B. 1993. Germinação de sementes In: AGUIAR, I.B. de; PIÑARODRIGUES, F.C.M.; FIGLIOLIA, M.B. Sementes florestais tropicais. Brasília: ABRATES, p. 83-135.

BÜLOW, J. F.W. V.; CARMONA, R.; PARENTE, T. V. 1994. Armazenamento e tratamento de sementes de pitanga-vermelha-do-cerrado (Eugenia calycina). Pesquisa Agropecuária Brasileira, Brasília, v.29, n.6, p.961-970.

CARNEIRO, J. G. A. 1987. Armazenamento de sementes florestais. Curitiba: FUPEF, 35p.

CARVALHO, N. M.; NAKAGAWA, J. 2000. Sementes: ciência, tecnologia e produção. 4. ed. Jaboticabal: FUNEP.

CARVALHO, N. M.; NAKAGAWA, J. 1988. Sementes: ciência, tecnologia e produção. 3.ed. Campinas: Fundação Cargill, 424p.

CASTRO, R. D.; BRADFORD, K. J.; HILHORST, H. W. M. 2004. Desenvolvimento de sementes e conteúdo de água. In: FERREIRA, A.G.; BORGHETTI, F. Germinação: do básico ao aplicado. Porto Alegre: Artmed. p.51-67.

CHIN, H.F.; HOR, Y.L.; LASSIM, M.B. 1989. Identification of recalcitrant seeds. Seed Science and Technology, Zurich, v.12, p.429-436.

DANNER, M. A.; CITADIN, I.; SASSO, S. A. Z.; AMBROSIO, R.; WAGNER JÚNIOR, A. 2011. Armazenamento a vácuo prolonga a viabilidade de sementes de jabuticabeira. Revista Brasileira de Fruticultura, Jaboticabal, v.33, n.1, p. 246-252.

DAVANÇO, T.; TANADA-PALMU, P.; GROSSO, C. 2007. Filmes compostos de gelatina, triacetina, ácido esteárico ou capróico: efeito do $\mathrm{pH}$ e da adição de surfactantes sobre a funcionalidade dos filmes. Ciência e Tecnologia de Alimentos, Campinas, v.27, n. 2, p. 408-416. 
DUAN, X.; BURRIS, J.S. 1997. Seed physiology, production e technology. Crop Science, Madison, v.37, n.2, p.515-520.

FOWLER, J. A. P. 2000. Superação de dormência e armazenamento de sementes de espécies florestais. In: GALVÃO, A.P.M (Org.). Reflorestamento de propriedades rurais para fins produtivos e ambientais: um guia para ações municipais e regionais. Brasília, DF: Embrapa Comunicação para Transferência de Tecnologia. Colombo, Embrapa Florestas, p.77-99.

GENTIL, D. F. O.; FERREIRA, S. A. N. 1999. Viabilidade e superação da dormência em sementes de araçá-boi (Eugenia stipitata ssp. sororia). Acta Amazonica, Manaus, v.29, p.21-31.

LAMARCA, E. V.; SILVA, C. V.; BARBEDO, C. J. 2011. Limites térmicos para a germinação em função da origem de sementes de espécies de Eugenia (Myrtaceae) nativas do Brasil. Acta Botanica Brasileira, Belo Horizonte, v, 25.

LORENZI, H. 1992. Árvores brasileiras: manual de identificação e cultivo de plantas arbóreas nativas do Brasil. Nova Odessa: Plantarum, 352p.

LORENZI, H. 2002. Árvores Brasileiras: Manual de Identificação e Cultivo de Plantas Arbóreas do Brasil, $4^{\mathrm{a}}$ edição, Nova Odessa, SP. Instituto Plantarum, v.1, 281p.

MALUF, A. M.; BILIA, D. A.C.; BARBEDO, C. J. 2003. Drying and storage of Eugenia involucrata DC. seeds. Scientia Agricola, Piracicaba, v.60, p.471-475.

MARCOS FILHO, J. 2005. Fisiologia de sementes de plantas cultivadas. Piracicaba: FEALQ, 495p. MENEZES, N. L. 2003. A semente e sua germinação. Santa Maria: UFSM.

PIÑA-RODRIGUES, F. C. M.; FIGLIOLIA, M.B.; PEIXOTO, M.C. 2004. Tecnologia de sementes: Testes de qualidade. In: FERREIRA, A.G.; BORGHETTI, F. Germinação - do básico ao aplicado. Porto Alegre: Artmed, p. 265-282.

PIROLA, K., WAGNER JÚNIOR, A., CASSOL, D. A., AlEGRETTI, A. L., MAZARO, S. M., CITADIN, I. 2009. Influência do armazenamento sobre a germinação das sementes de jabuticabeiras 'açú' e ‘de cabinho' In: XIV Seminário de Iniciação Científica e Tecnológica da UTFPR, 2009, Pato Branco. XIV Seminário de Iniciação Científica e Tecnológica da UTFPR. cd-rom.

RIZZINI, C.T. 1970. Efeito tegumentar na germinação de Eugenia dysenterica DC. (Myrtaceae). Revista Brasileira de Biologia, Rio de Janeiro, v. 30, n. 3, p. 381-402.

SAUER, D. B. 1992. Storage of grains and their products. 4.ed. St. Paul, Minnesota: American Association of Cereal Chemists, 615p.

SCALON, S. de P. Q.; SCALON FILHO, H.; RIGONI M. R. 2004. Armazenamento e germinação de sementes de uvaia Eugenia uvalha Cambess. Ciência agrotécnica, Lavras, v. 28, n. 6, p. 1228-1234.

SOUZA JÚNIOR, J. R. de; SOUZA, J. R. M. de; FURTADO, G. de F.; ALVINO, F. C. G.; SILVA, H. de S.; SILVA, S. S. da. 2011. Diagnostico de armazenamento de grãos em pequenas propriedades do município de Pombal - PB. Revista Agropecuária Científica no Semi-Árido, Patos, v. 07, n. 03, p. $36-40$.

WIELWICKI, A. P.; LEONHARDT, C.; SCHLINDWEIN, G.; MEDEIROS, A. C. S. 2006. Proposta de Padrões de germinação e teor de água para sementes de algumas espécies florestais presentes na região sul do Brasil. Revista Brasileira de Sementes, Londrina, v. 28, n. 3, p. 191-197.

ZONTA, E. P.; MACHADO, A. A. 1984. Sanest - Sistema de Análise Estatística para Microcomputadores. Pelotas: UFPel, 75p. 